\title{
Hankering after Europe
}

\section{Vienna}

As an indication of its desire for closer contacts with the European Community, Austria gave an enthusiastic reception to the Eureka conference of Industry Ministers in Vienna last week (some of the meeting's decisions are covered on page 652). There is "no alternative" to joining the EC if Austria wants to improve its science and technology base, says new Austrian Science Minister Erhard Busek. Most important, he says, would be gaining access to EC science programmes.

Even if it applied soon for EC membership, Austria could not hope to be accepted before 1992, when the single market is supposed to come into effect.

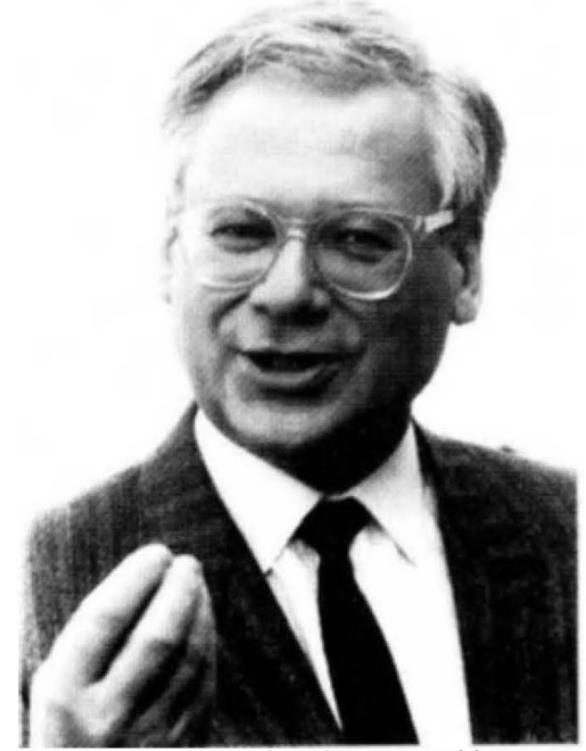

Busek - increasing Austrian competitiveness.

Whether to apply or not is at the top of the political agenda, but the question may not be settled for many months. Busek jokes that "Hungary may be a member sooner than Austria". In the meantime, this small country has other pressing needs in the areas of education and science.

Busek inherited a difficult task from his predecessor, biochemist Hans Tuppy. With less than 18 months remaining in the term of the current coalition government, Busek has to soothe interest groups in the universities and industry while trying to drum up more $R \& D$ investment from government and industry sources. Although Tuppy achieved a significant increase in the Science Ministry budget for 1989, pressure from critics, especially those in universities, helped to force him from office.

Busek's first priority is to negotiate another budget increase for 1990 . The government promised in 1987 that Austria would increase total spending on research investment from public and private sources equal to 1.5 per cent of the gross domestic product. Although far less than the 2.5 to 3.0 per cent invested by West Germany, Japan and the United States, this would nevertheless be a substantial increase over the current level of 1.3 per cent investment (roughly 21,900 million Austrian schillings, or US $\$ 1,564$ million, in 1989).

It seems likely that the government will have trouble keeping its promise, although Busek remains hopeful. Whatever the outcome, Busek intends to pursue a strategy of filling niches in order to increase Austrian competitiveness. He hopes to attract more research institutes like the Institute for Molecular Pathology (IMP), founded jointly in Vienna last year by Boehringer Ingelheim and Genentech with Austrian state support.

More recently, a new institute for laser research has been announced at the Mountain University of Leoben, and Siemens and Philips have expanded their efforts in microelectronics research in Austria.

One niche in which Austria does not necessarily belong, said Busek, is space travel. Austria has agreed to pay the Soviet Union 150 million schillings (US $\$ 10.7$ million) to put an Austrian astronaut on the Soviet MIR space station in late 1991 or early 1992. Busek is sceptical about the scientific merit of this arrangement, but he says that it was mostly a "political decision with which we have to live".

Busek supports the current initiative of the Austrian Academy of Sciences to establish guidelines for genetic engineering as a way to secure the future of biotechnology research in Austria. Though adherence will be voluntary, Busek sees the guidelines as a sign of responsibility on the part of researchers. In addition, the Ministry has commissioned a report, due next February, on how best to regulate genetic engineering both in research laboratories and in production. Karl Schlögl, who chairs the Academy committee responsible for the new guidelines, sees his work as pre-empting the actions of a parliament that might all too easily decide to ban genetic engineering. Schlögl hopes to present the committee's recommended guidelines by the autumn of this year.

Busek stands by the long-term goal of the research community that 3 per cent of the Austrian gross domestic product be spent on research and development by the mid-1990s. Busek hopes this goal is realistic, but recognizes that priorities will have to change tremendously for it to be achieved. "It would be better to put our billions into science and technology rather than the Autobahn. We might even get some support on this from the environmentalists."

\section{Japan joins in at the last minute}

\section{Tokyo}

JAPAN will at last be able to join Europe, Canada and the United States in the construction phase of the US Space Station. A motion approving the inter-governmental agreement between the United States and Japan on the station was passed last week by the Diet.

The motion has been stalled in the Diet for months because of the opposition's boycott of Diet deliberations to protest the Recruit scandal, the discovery that many key members of the ruling Liberal Democratic Party made huge profits through the buying and selling of shares. And there were fears that the motion would not pass before the summer recess of the Diet (Nature 339, 495; 1989).

But despite opposition objections to possible military uses of the space station, the motion finally passed on the last day of Diet deliberations. David Swinbanks

\section{INSAT}

\section{Indian hopes and satellite dented}

\section{New Delhi}

THE luckless Indian space programme faltered again when its newest communications satellite, Insat-1D, was severely damaged in an accident at Cape Canaveral, Florida, barely a week before the scheduled launch on 29 June. The setback jeopardizes India's $\$ 2,000$ million domestic satellite communications network: only Insat-1B is now fully operational, but it is reaching the end of its six-year design lifetime. Insat-1A failed within two weeks of its launch, and Insat-1C is operating at less than half capacity after a power supply failure.

The \$53-million dollar satellite, made by Ford Aerospace in the United States, was hit by a falling 45-kg hook when a cable on a service crane broke. At best repairs will take many weeks. The launch, using a Delta rocket, was to have been the first commercial operation by McDonnell Douglas, who leased facilities at Cape Canaveral from the US Air Force.

The accident has dashed hopes of replacing Insat-1B during its lifetime and threatens not only India's 272 television stations but also the politicians who hope to use their services in the November general elections.

The only hope for the Indian Department of Space seems to be somehow to extend the life of Insat-1B beyond September, because none of Intelsat's three Indian Ocean satellites has any spare capacity. Intelsat may try to help India by securing one of the yet to be launched Arabsat satellites, but this will not solve the short-term crisis as no suitable launcher is available for another 18 months. K. S. Jayaraman 